Mariia Shchemynenko,

Student,

College of Trade and Economics of Kyiv National University of Trade and Economics, 2/4, Lvivska str., Kyiv, 03115, Ukraine, ORCID: 0000-0002-1155-4346

Tatyana Osadcha, Teacher of economic disciplines, College of Trade and Economics of Kyiv National University of Trade and Economics, 2/4, Lvivska str., Kyiv, 03115, Ukraine,

ORCID: 0000-0002-4434-1742

\title{
EVENT TOURISM AS A FACTOR OF ECONOMIC DEVELOPMENT
}

The article considers the events industry, future prospects events in tourism, business development by events and why event needs to be developed in Ukraine.An event is a new segment of tourism industry. Not many people know the very essence of an event in its totality and in all its details. This article is aimed to define the concept of «event» and consider development problems of events in Ukraine. Also in this article we consider statistic of interested in event tourism and per cent of knowledgeable and uninformed people about event tourism.

Keywords :event, tourism, industry.

Relevance of research topic. Nowadays market of tourism is saturated and on it reigns competition and the struggle for client. Many countries in the process of competition with each other started developing new type of tourism it is an event tourism.

We have two definition of event tourism which details the whole essence of this concept:

1. Event tourism is both a field of study and a globally significant sector of the economy. For individual events, event tourism means taking a marketing orientation to attract tourists, sometimes as an additional segment and sometimes as the core business.

2. Event tourism is a type of tourism, trips in which are timed to coincide with any events. Events may relate to culture, sports, business, etc. Examples of events causing a surge in event tourism: Olympics, football world championships, rock festivals, film festivals, carnivals, economic forums, air shows. 
Event is a relatively new concept in tourism industry. Today events are rapidly evolving and gaining strength.

Now, the question is: why? So many things are happening in the world, for example: festivals, carnivals, parties, sport competitions, etc. (types of event will be considered later).

Accordingly, people are very interested in being at the centre of an event.

This is the relevance of the events - this is the event itself. Events always attract many people. More and more new events occur daily in the world, therefore, the event as a type of tourism industry will also remain relevant in the near future.

A lot of people without even realizing it, go to the event, for example: a trip to the carnival in Rio de Janeiro is an event, because we have a target to visit the carnival, and the event itself is the carnival.

Events have great potential in the development of their own business and tourism industry generally. This aspect will be considered later as well.

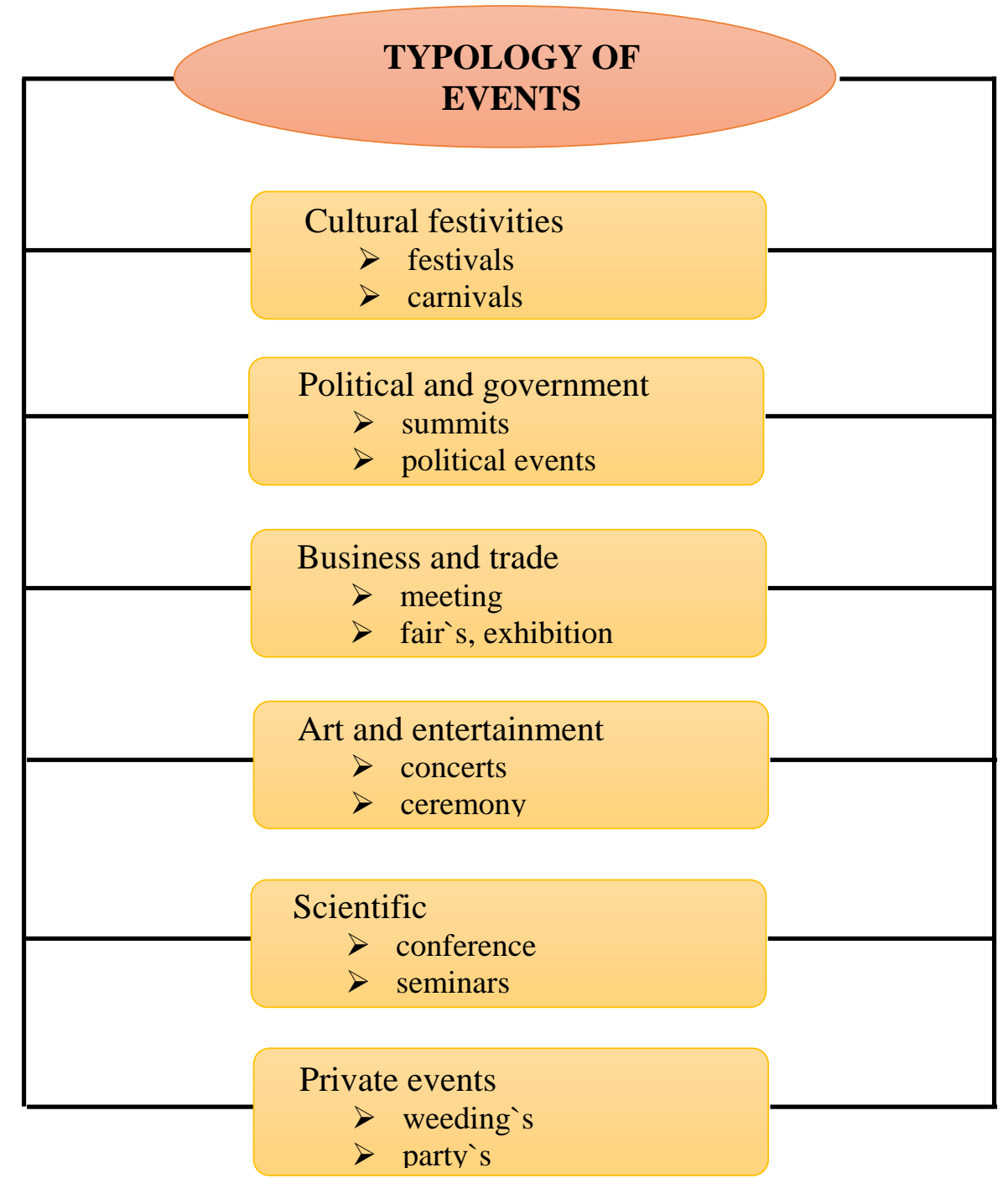

Source: Event tourism and event-management - Typology of events (Reference 3)

As started earlier, an event is a new segment of tourism industry. It is necessary to consider the components of the events in order to understand what is what. 
This is very important, because if the concept is not addressed in detail, we cannot understand a sense of this or that situation.

Let's consider the typology of events. This table clearly illustrates all existing types of events. It will help in order to further guidance in the material.

Business development through events in Ukraine. Worldwide event tourism is a powerful catalyst for the economy of a particular country.For example, Oktoberfest in Germany, where many tourists come from all over the world, which in turn brings good profit and a high popularity to the country, which is also very important. Thus, we can achieve a constant influx of tourists.

And what about Ukraine? It is very profitable to develop your business with the help of events. In Ukraine events is a new segment in tourism market that is why there is a lack of staff in it.

Let`s consider the statistics.

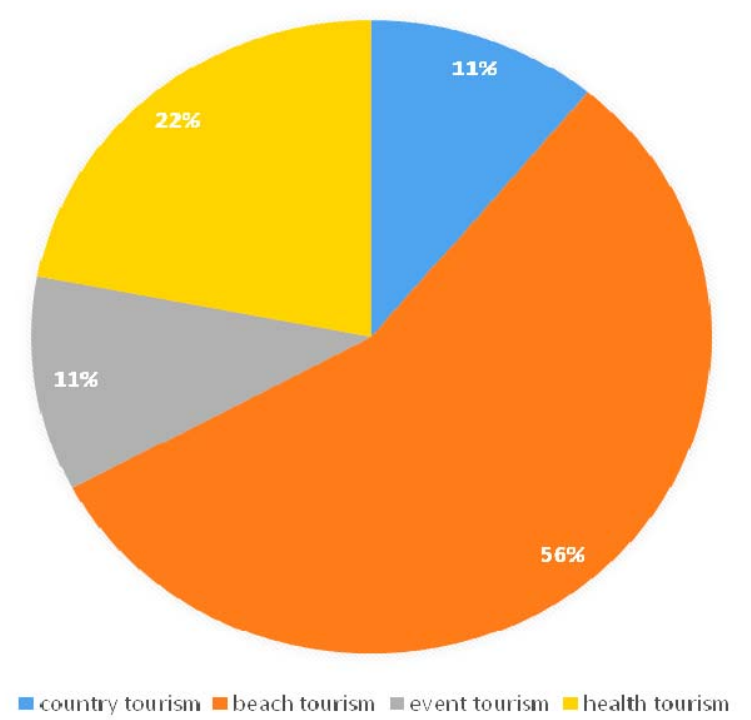

Figure 1. Preference tourists towards types of tourism

Source: Development of the event tourism abroad and in Russia

But, one of the main issues is that this industryhas been working only for 15 yearsin Ukrainian market and an obstacle of the development is a shortage of skills in the market and reluctance of Ukrainian costumers to creative solutions and shopping.

Standard resorts are in Turkey and Egypt, therefore people are apprehensive about something new.

Unfortunately, in Ukraine, events are not so well developed, but it is in this industry that the development prospects are quite high.

If we take the capital, the Atlas Weekend is a rather successful project, which attracts many tourists and world-famous music groups.

Other cities of Ukraine also have the necessary resources for development.

Odessa has one of the largest sporting festivals - «Z-Games». 
Lviv also does not stand aside: many festivals are devoted to coffee, wine, chocolate, etc.

In Korosten there is a festival dedicated to potato pancakes, which is held every autumn.

Summing up, we can say that Ukraine has many resources and prospects; they just need to be properly developed.

Analysis of recent researcher and publications. The concept of the event is now quite actively researched and studied.

Many consider the event as a general concept, others go into further and consider the impact of the events on tourism and the economy as a whole.

The authors of the study are not only professors or academicians, but also students from different universities, often these are masters and bachelors.

The research is presented not only asarticles, but rather as thematic compendiums or books.

Avery famous man in this industry is Donald Getz, who wrote the following books:

1. «Event studies. Theory, research and policy for planned events».

2. «Progress and prospects for event tourism research».

Conclusion. Events is a pretty interesting kind of tourism industry. Event requires more development and promotion for profit-making.We have examined in detail the concept of the event itself.We examined the statistics of preferences of tourists and found out that event tourism is a developing type of tourism and that one of the most popular types of tourism is beach tourism. It is worth considering that with the help of events you can attract customers of different ages.

Summing up, we can say that thanks to the events you can profitably develop your business.

\section{REFERENCES}

1. BizInfo Journal (2015). The role of events in tourism development, Vol. 6, Number 2, pp. 83-97.

2. Getz Donald. Event management and event tourism $\left(2^{\text {nd }}\right.$ ed. $)$ - New York: Cognizant, 2005, pp. 23-27.

3. Vent tourism and event management. Retrieved from:

http://tourlib.net/statti_tourism/alekseeva.htm

4. Potential of Ukraine in development of the event tourism: how to attract visitors? Retrieved from:

https://sostav.ua/publication/potentsial-ukrainy-v-razvitii-sobytijnogo-turizmakak-privlech-vizityorov-72069.html

5. Develoment of the event tourism broad and in Russia. Retrieved from:

https://studfile.net/preview/7440569/page:3/

6. Don Getz. Festivals and event, tourism, 25 September 2015. Retrieved from: https://link.springer.com/referenceworkentry/10.1007\%2F978-3-319-01669-6_84-1 